\title{
Extraction of Essential Oil D-Limonene from Sweet Orange Peels by Simple Distillation
}

\author{
Ramgopal K, Sreekanteshwara S, Vijay Bhaskar S A, Vinodh S M, Mr.N.Sesha \\ Asst. Professor, Department of Chemical Engineering, BMS College of Engineering, Bangalore, India
}

\begin{abstract}
Essential oils are highly concentrated substances, which are extracted from fruit peels, flowers, leaves, stems, roots and seeds. These oils are often used for their flavor and their therapeutic or odiferous properties, in a wide selection products such as foods, medicines and cosmetics. Although there are a wide variety of methods available to extract essential oils, it is a time consuming process in which the quality of the final product varies depending on the preferred process. In this study oils are extracted from orange peels by simple distillation which is both effective and cost efficient.
\end{abstract}

\section{Introduction and Objective}

Mankind has used many plants for medicinal purposes for thousands of years. Oils from plants have been used in the embalming processes, medicine and purification rituals. The 'fragrant pharmacy' contains compounds which have a wide range of biochemical effects. With the continual bombardment of viral, parasitic and bacterial fungal contamination in our world, essential oils play an important role in protecting our bodies from this onslaught of pathogens. Essential oils give much needed support to the immune system.

Essential oils are frequently referred to as the "life force" of plants. Unlike fatty oils these essential oils are volatile and highly concentrated. The amount of essential oils found in plants varies between $0.01 \%$ to $10 \%$ resulting in tons of plants required for just a few hundred pounds of oil. These oils contain potent antimicrobial factors with a wide range of therapeutic constituents.

Essential oils cannot be substituted with synthetics and contain a full spectrum of compounds which simply cannot be duplicated. The most effective way to use most essential oils is by external application inhalation or internal consumption. They are used in cosmetic lotions, bath soaps, hair rinses, perfumes and room sprays.

Distillation is the main method used to extract essential oils. It is based on the principle that when plant material is placed in boiling water, the essential oil in it evaporates with steam. Upon condensation of the steam and oil the oil separates from water and can be collected. Plants or rinds of fruit are crushed to release their oils. This basic study focuses on extracting the simple organic compound, D-Limonene from orange peels using the simple distillation method.

\section{Experimental Methods}

- A simple distillation set up consisting of a $500 \mathrm{ml}$ round bottomed flask, glass condenser, thermometer and Bunsen burner was assembled.

- Oranges were procured locally and peeled using a razor blade.

- The sample was checked to ensure that none of the white flesh under the rind was part of the sample.

- The mass of the sample was determined using an electronic scale.

- The sample of orange peels was added to the round bottomed flask which was filled to two thirds of its capacity with solvent. The condenser was turned on and after preheating the sample heating was done at a constant temperature for two hours.

- Presence of oil in the condensate was confirmed by the cloudy appearance on top of the distillate.

- The distillate was transferred to a separating funnel and allowed to separate for 30 minutes. D-Limonene was separated and isolated.

- The experiment was repeated for various input masses of orange peels and various solvents.

III. Experimental Results and Data Tables

Table 1 Extraction of D-Limonene Using Orange Peels (Data for Three Solvents)

\begin{tabular}{|l|l|l|l|l|l|}
\hline SOLVENT & $\begin{array}{l}\text { WEIGHT of } \\
\text { PEELS(GMS) }\end{array}$ & $\begin{array}{l}\text { VOLUME of } \\
\text { SOLVENT(ML) }\end{array}$ & $\begin{array}{l}\text { TEMP } \\
\text { (C) }\end{array}$ & $\begin{array}{l}\text { TIME } \\
\text { HEATING(MIN) }\end{array}$ & $\begin{array}{l}\text { VOLUME of OIL } \\
\text { COLLECTED(ML) }\end{array}$ \\
\hline \multirow{3}{*}{ METHANOL } & 200 & 150 & 55 & 100 & 04 \\
\cline { 2 - 6 } & 200 & 150 & 55 & 120 & 05 \\
\cline { 2 - 6 } & 200 & 150 & 55 & 150 & 07 \\
\hline
\end{tabular}


Extraction of Essential Oil D-Limonene from Sweet Orange Peels by Simple Distillation

\begin{tabular}{|c|c|c|c|c|c|}
\hline \multirow[t]{3}{*}{ HEXANE } & 200 & 150 & 58 & 90 & 05 \\
\hline & 200 & 150 & 58 & 120 & 06 \\
\hline & 200 & 150 & 58 & 150 & 07 \\
\hline \multirow{3}{*}{$\begin{array}{l}\text { DISTILLED } \\
\text { WATER }\end{array}$} & 200 & 150 & 90 & 90 & 07 \\
\hline & 200 & 150 & 90 & 120 & 08 \\
\hline & 200 & 150 & 90 & 150 & 08 \\
\hline
\end{tabular}

Table 2 Extraction of D-Limonene Using Orange Peel Powder (Data for Three Solvents)

\begin{tabular}{|l|l|l|l|l|l|}
\hline SOLVENT & $\begin{array}{l}\text { WEIGHT OF } \\
\text { PEELS(GMS) }\end{array}$ & $\begin{array}{l}\text { VOLUME OF } \\
\text { SOLVENT(ML) }\end{array}$ & $\begin{array}{l}\text { TEMP } \\
(\mathbf{C})\end{array}$ & $\begin{array}{l}\text { TIME OF } \\
\text { HEATING(MIN) }\end{array}$ & $\begin{array}{l}\text { VOLUME OF OIL } \\
\text { COLLECTED(ML) }\end{array}$ \\
\hline \multirow{5}{*}{ METHANOL } & 200 & 150 & 55 & 100 & 03 \\
\cline { 2 - 6 } & 200 & 150 & 55 & 120 & 04 \\
\cline { 2 - 6 } & 200 & 150 & 55 & 150 & 05 \\
\hline \multirow{5}{*}{ HEXANE } & 200 & 150 & & & \\
& 200 & 150 & 58 & 90 & 04 \\
\cline { 2 - 6 } & 200 & 150 & 58 & 120 & 05 \\
\hline \multirow{3}{*}{ WISTILLED } & 200 & & 58 & 150 & 05 \\
\cline { 2 - 6 } & 200 & 150 & & & 04 \\
\cline { 2 - 6 } & 200 & 150 & 90 & 90 & 05 \\
\hline
\end{tabular}

IV. Discussion of Results and Conclusion

Simple distillation method was used for the extraction of D-Limonene from fresh and finely ground orange peels. Three solvents namely methanol, hexane and distilled water were tried out. Experimental results indicate that the volume of oil extracted increases with the time of heating in all cases. The maximum yield of oil is obtained using distilled water as a solvent. This result is favorable as both methanol and hexane are toxic solvents and the extracted oil will have to be stripped of these solvents before useful usage.

\section{References}

[1]. Ramgopal et.al, B.E project report, department of chemical engineering, BMSCE Bangalore, India, 2016. 